\title{
The Comparison of Cardiovascular Endurance Based on the Blood Types for the Students of Sport Science Faculty of Jambi University
}

\author{
Wawan Junresti ${ }^{1 *}$ and Sri Murniati ${ }^{2}$ \\ ${ }^{1,2}$ Faculty of Sports Sciences, University of Jambi, Jambi, Indonesia \\ *Corresponding author. Email: wawanfik@unja.ac.id
}

\begin{abstract}
This study aims to examine the comparison of cardiovascular endurance based on the blood type for the students of Sport science faculty, Jambi University, as well as to determine what blood type has better cardiovascular endurance. This is a comparative descriptive study through survey method with 24 convenient samples. The instrument of this study used Multistage Fitness Test (MFT), then the data analysed using comparative descriptive and percentage. The result of this study illustrated that 1 participant $(4.1 \%)$ has very bad cardiovascular endurance. 2 participants (8.3\%) have bad cardiovascular endurance, 9 participants (37.6\%) in the medium category, 8 participants (33.3\%) in the good category, 4 participants $(16.7 \%)$ in the very good category. Next, for each blood types $\mathrm{AB}, \mathrm{A}, \mathrm{B}$, and $\mathrm{O}, \mathrm{AB}$ average is 41.5 in medium category, the average of $B$ is 41.63 in medium category, the average of $A$ is 44.62 in medium category and the average of $\mathrm{O}$ is 45.68 in good category. Based on the result, it can be concluded that the blood type of $\mathrm{O}$ has better cardiovascular endurance level than the blood types of $\mathrm{A}, \mathrm{B}$, and $\mathrm{AB}$.
\end{abstract}

Keywords: Cardiovascular Resistance, Blood Types

\section{INTRODUCTION}

Sport is one activity to improve human resources. Regular and continuous exercise can improve physical and mental quality of people. For that reason, coaching in the field of sports needs to be considered, especially the improvement of physical and mental conditions as an effort to form Indonesian people who have good personality, high discipline and sportsmanship. Besides on improving physical and mental quality, sports also elevates the image of the nation and nationality through the highest achievements.

One effort to make the nation proud is through sports. Therefore, educational and coaching of sports must be improved in accordance with the objectives of sports education, namely the fostering and enhancement of sports development were addressed to the formation of well prepared physically and mentally human beings. Because the success of a nation in the development depends on the physical and mental abilities of its people.

Sport is one of the physical activities that requires more energy as well as the energy needs / calories of very heavy athletes. Usually exercise is performed for a relatively long time, higher intensity, the movements made are explosive and continuously. A sport requires skills related to body fitness, namely strength, endurance, speed and agility. Endurance is the ability of a person to carry out motion with his entire body in a long time and with a moderate to fast tempo without experiencing pain and severe fatigue [1].

According to Muhajir and Jaja [2] Cardiovascular Endurance is a person's ability to do work in a relatively long time. Another term often used is respiratori-cardio-vaskulatoir-endurance, which is the endurance associated with respiratory, and blood circulation. Therefore, the form of exercise to improve endurance-cardiovascular endurance is called secondary ergo-system which is trained through the improvement of primary ergo-system (nervous system-muscles and skeletal bones).

Cardiovascular endurance is the ability of the lungs, heart and blood vessels to deliver a number of oxygen and nutrients to cells to meet the needs of physical activity that lasts for a long time [3]. Djoko Pekik Irianto [4] stated that the heart-lung power is the ability of the lungs and heart to supply oxygen for longterm muscle work.

Technically, the cardio (heart), vascular (blood vessel), respiration (lung and ventilation), and aerobic (Working with oxygen) are different but these terms are related to each other. Furthermore, the system that works on cardiovascular endurance is a component of 
the heart's work to pump oxygen-rich blood to other body parts and the ability to complete and recover from physical activity.

Based on some of the opinions above, it can be concluded that cardiovascular endurance is the ability of the heart and lungs to supply oxygen throughout the body in an activity for a certain period of time. To be able to supply oxygen optimally throughout the body, of course it takes a good blood hemoglobin level in order to bind and deliver oxygen throughout the body in meeting the body's metabolic needs.

One of the factors that influence hemoglobin levels in the blood is the blood group itself, as it is known that antigens of different blood groups have a very varied clinical significance, and the most important are $\mathrm{ABO}$ and rhesus $(\mathrm{Rh})$ blood groups.

Jambi University is one of the universities in Jambi Province, Jambi University currently has 13 faculties, and one of these faculties is the Faculty of Sports Science. The Faculty of Sport Science at University of Jambi was established in 2014, but FIK Unja became one of the most favorite faculties for students, judging by the number of students who registere each year.

The Faculty of Sport Science, University of Jambi is a representation of students who have good physical health and fitness, because in the curriculum there are several courses that are really studied for the formation of the physical condition of students and athletes in general. There are several courses such as the formation of physical conditions, athletics, coaching methods and others.

Based on the observations and results of the researchers' discussion with lecturers who teach athletic subjects, at present students still do not have good cardiovascular endurance. Therefore, it is feared that the course from the beginning to the end will not run as it should and can hamper the course of the lecture for the student.

As we know, many factors can affect the capacity of cardiovascular endurance for students themselves, including age, food, physical activity, exercise, heredity, nutrition, rest, blood hemoglobin and blood type of the students.

Based on the description above, the authors were interested in examine how is the comparison of cardiovascular endurance of the students based on the blood type who are currently taking athletic courses. After getting the research data, then it was seen what blood type that can make a good cardiovascular endurance, so that it can be a recommendation

\section{LITERARUR REVIEW}

A. Cardiovascular Endurance

Endurance is one of the main bio-motor components in every sports. The components of endurance biomotor are generally used as benchmarks to determine the level of physical fitness. People who have good endurance will certainly be able to do activities without experiencing significant fatigue in a relatively long period of time.

According to Mochamad Sajoto [5], there are two kinds of endurance, namely:

a) General endurance is the ability of a person to use the heart, lungs and blood circulation system effectively and efficiently (cardiovascular endurance).

b) Muscle endurance is the ability of a person to use his muscles to contract continuously in a relatively long time with a certain burden.

Cardiovascular endurance is the ability of the lungs, heart and blood vessels to deliver a number of oxygen and nutrients to cells to meet the needs of physical activity that lasts for a long time [3]. Djoko Pekik Irianto [4] stated that the heart-lung power is the ability of the lungs and heart to supply oxygen for longtime muscle work.

General cardiovascular endurance is a person's ability to use the heart, lungs and blood circulation system effectively and efficiently to carry out continuous work which involves the contraction of a number of muscles with high intensity in a long time.

Cardiovascular endurance or heart endurance is the ability to provide oxygen to the muscles continuously for a long period of time when doing physical activity by the circulatory system and respiratory system. This is the most important component in the profile of human physiology. Cardiovascular endurance according to [6], endurance of the pulmonary heart is the ability of the heart system, lungs and blood vessels to function optimally when carrying out daily activities especially those involving stamina. According to Djoko Pekik Irianto [4], cardio respiration endurance is a condition where a person's heart is able to work by overcoming workloads during a certain work. Likewise Sumarjono [7], heart endurance and blood circulation can be measured by the ability to perform heavy tasks continuously, which includes a large group of muscles for a long time.

According to Rusli Lautan [8] technically, cardio (heart), vascular (blood vessels), respiration (lungs and ventilation), and aerobics (working with oxygen) are different but these terms are related to each other. It was further explained that cardiovascular endurance is a component of the heart's work to pump oxygen-rich blood to other parts of the body and the ability to 
complete and recover from physical activity.

Based on some of the opinions of the experts above it can be concluded that cardiovascular endurance is the maximum ability of a person to use oxygen, it means that cardiovascular functional capacity can improve one's quality of life. it can also be concluded that cardiovascular endurance is a person's ability to use the cardiovascular system to carry out work continuously with high intensity for a long period of time without experiencing fatigue.

According to Rusli Lutan [8], the intensity, specificity, frequency, individual uniqueness and motivation to exercise are some of the factors that affect cardiovascular endurance. Health and nutrition factors that meet the dose of exercise to improve cardiovascular endurance. Good cardiovascular endurance is the interaction of various factors with some other complementary body components.

Furthermore, Djoko Pekik Irianto, [4] stated that the factors that affect cardiovascular endurance are as follows:

1) Food and Nutrition Factors

2) Sleep and Rest Factors

3) Factors of Healthy Lifestyle Habits

4) Environmental Factors

5) Exercise and Sports Factors

Based on the opinion of the experts above, the factors that influence cardiovascular endurance are exercise factors. According to Sukadiyanto [9] the goal of endurance training is to improve one's ability to overcome fatigue during activity. Fatigue in this context is fatigue both physically and psychologically. Endurance training will have an impact on the quality of the cardiovascular system, respiratory and circulatory system.

According to Muhajir and Jaja [2], Cardiovascular Endurance is a person's ability to do work in a relatively long time. Another term often used is respiratori-cardio-vaskulatoir-endurance, which is the endurance associated with respiratory breathing, and blood circulation. Therefore, this form of exercise to improve endurance-cardiovascular endurance is called secondary ergo-system which is trained through enhancement of primary ergo-system (nervous systemmuscles and skeletal bones).

From some of the above opinions it is clear that the main substance of cardiovascular endurance is how much blood is able to circulate oxygen $(\mathrm{O} 2)$ throughout the body during physical activity or exercise. in other words the element that is responsible for binding oxygen from the air is blood hemoglobin $(\mathrm{Hb})$ which is influenced by blood type.

There are some various techniques, methods and procedures that can be used to measure cardiovascular endurance. There are several choices about techniques that can be done according to the facilities that available. According to Junusul Hairy [3] various kinds of cardiovascular fitness tests are as follows:

1) 2400 meter test run

2) Harvard Step Test

3) Astrand Rhyming Test

4) Multi Stage Fitness Test / Bleep Test

5) Kasch Pulse Recovery Test

6) Step Test

7) 4800 meters fast walking test

From several forms of tests to measure cardiovascular endurance that have been described above, researchers chose the form of the Multy Stage Fitness Test / Bleep Test which is one of the tests whose validity is quite accurate, so the results obtained are more accurate and reliable.

\section{B. Blood Types}

Blood is a vehicle for long-distance mass transport in the body for various materials between cells and the external environment and among the cells themselves. Blood consists of plasma complex fluid in which cellular elements include erythrocytes, leukocytes, and platelets. Erythrocytes (red blood cells) are essentially hemoglobin sacs wrapped in plasma membranes that carry $\mathrm{O} 2$ in the blood. Leukocytes (white blood cells) immune system defense units, transported in the blood where injury or invasion of micro organisms that cause disease. Platelets are important in homeostasis, stopping bleeding from injured vessels. If the blood is disrupted, then all metabolic processes will be disrupted as well.

According to Sentosa Giriwijoyo [10] that in the life with activities that are always relaxed, circulation is also always slow. Impacts of erythrocytes with bloodforming walls or between each other are also mild. The result is that erythrocytes can reach an older age (120 days). Because erythrocytes can reach an older age, the turnover cycle is slow. So the red bone marrow as an erythrocyte maker does not need to be too active as a blood donor, people with such a pattern of life are less beneficial both to themselves and to their blood recipients, because blood is a liquid network consisting of two parts, namely blood plasma and blood cells.

Blood cells consist of three types, namely erythrocytes, leukocytes and platelets. The overall blood volume is one twelfth of body weight or about five liters. About 55\% are blood plasma, while the rest $45 \%$ consists of blood cells, [11]. The amount of blood in each person is not the same depending on age, occupation, and the condition of the heart or blood vessels [12].

Exercise will cause blood circulation to be faster so that the collision between erythrocytes and / or 
against the walls of blood vessels also becomes harder. Fragile old erythrocytes cannot survive further. By doing regular and continuing exercise, erythrocytes are less likely to reach old age (reaching 120 days). This situation requires the red bone marrow to always actively form new erythrocytes thus, the loss as a donor for both himself and the recipient of blood will not happen. Red bone marrow activity level is also an indicator of the degree of physical fitness of a person.

According to Koes Iriyanto [13] blood is composed of four main parts namely: red blood cells (erythrocytes) white blood cells (leukocytes), pieces of blood (platelets), and blood fluid (blood plasma). However, if we look carefully under a microscope, it turns out that in the blood there are substances that differ in different substances, including agglutinogen, which is a type of protein found in red blood cells.

There are two kinds of aglutinogen, namely aglutinogen A and aglutinogen B. In 1900, an Austrian doctor Karl Landsteiner found the differences in antigens and antibodies contained in human blood. On this basis he divided blood groups into four groups, namely: blood type $\mathrm{A}$, blood type $\mathrm{B}$, blood type $\mathrm{AB}$, and blood type $\mathrm{O}$. Each person inherits a blood type gene from each parent to form their own blood type. For example, if you have blood type A and your husband has blood type $\mathrm{AB}$. So there are three possible blood types of drought, namely A, B or AB. Most likely, your child will have blood type A because type A looks more dominant.

Blood is a very important network in the body of living creture because it plays a very vital role, namely as a medium of transport of nutrients and oxygen to the entire body in order to carry out metabolism. In humans, the volume of blood around $8 \%$ of body weight. For example someone who weighs $50 \mathrm{~kg}$, weighs more or less $0.08 \times 50 \mathrm{~kg}$ of blood. Approximately the volume of blood in the body that has a mass of $50 \mathrm{~kg}$ is 4 liters.

The blood itself consists of various types of blood cells, namely:

1. Red blood cells (erythrocytes), which carry oxygen and are red due to hemoglobin.

2. White blood cells (leukocytes), which fight disease.

3. Platelets (Trombocytes), which are very important in blood clotting

4. Eosinophil and Lymphocyte and various cells in other blood vessels.

The function of blood in the body are:

1. Supply the oxygen to muscles (captured by hemoglobin and carried by red blood cells)

2. As a medium for transporting nutrients and oxygen to the entire body in order to be able to metabolize to produce ATP.
3. Carrying carbon dioxide and metabolic waste to be excreted.

4. Carrying the hormone from its production site to the target organ.

5. Maintain body temperature because the blood in the arteries has heat.

6. White blood cells as the body's defense from microorganism infections.

7. Regulate acid-base balance to avoid cells damage by using hemoglobin, oxyhemoglobin, bicarbonate, phosphate, and plasma proteins.

Blood type is a special feature of the blood of an individual because of the different types of carbohydrates and proteins that are owned on the surface of the red blood cell membrane. Or it could be said, blood type is determined by the amount of substances (antigens) contained in individual red blood cells. There are 2 types of blood type, the most important of which are $\mathrm{ABO}$ and Rhesus (Rh factor). In the world there are actually around 46 types of antigens other than $\mathrm{ABO}$ and $\mathrm{Rh}$ antigens, only it's rarely found [14].

Hoffbrand [15] revealed that there were around 400 blood group antigens that had been reported. The clinical meaning of blood groups in blood transfusion is that individuals who do not have an antigen of a particular blood group might produce antibodies that react with these antigens, which may cause a transfusion reaction. These different blood group antigens have a very varied clinical significance, and the most important are $\mathrm{ABO}$ and rhesus $(\mathrm{Rh})$ blood groups.

Benjamini [16] stated that the investigation of various sera and red blood cells (RBCs) led Landsteiner (the discoverer of the $\mathrm{ABO}$ antigen group) to conclude that based on the presence of substances or antigens on the surface of erythrocytes, human RBC can be divided into four major groups:

(1) Erythrocytes with substance group A

(2) Erythrocytes with substance group B

(3) Erythrocytes with substance group A and B, and

(4) erythrocytes that do not have substance either group A or B.

These blood types are named sequentially as A, $\mathrm{B}, \mathrm{AB}$, and $\mathrm{O}$. Landsteiner further determined that individuals with blood type A have serum antibodies that can agglutinate erythrocytes in group $\mathrm{B}$, people with blood type B have antibodies that can agglutinate erythrocytes type $\mathrm{A}$; and individuals with blood type $\mathrm{AB}$ do not have antibodies to the alloantigen, whereas individuals with blood type $\mathrm{O}$ has antibodies that can agglutinate erythrocytes type $\mathrm{A}, \mathrm{B}$, and $\mathrm{AB}$. 
According to [7] the $\mathrm{ABO}$ system found by Austrian doctor, Landsteiner, is determined by substances / antigens contained in red blood cells. The following are the classification:

Table 1. Antigens in Blood Type

\begin{tabular}{|c|c|c|}
\hline Blood Types & Red Blood Cells & Blood Plasma \\
\hline A & Antigen A & Antibody B \\
\hline B & Antigen B & Antibody A \\
\hline AB & Antigen A\&B & There is no Antibody \\
\hline O & There is no Antigen & Antibody A\&B \\
\hline
\end{tabular}

(Sutomo 2007:1)

Blood group antigens are controlled by three alleles (A, B, and $\mathrm{O}$ ); $\mathrm{A}$ and $\mathrm{B}$ are dominant over $\mathrm{O}$ and co-dominant with each of them. This allele produces a transferase enzyme that adds to the terminal residual sugar on the surface of erythrocytes in its parental structure. Whereas type $\mathrm{O}$ is not active in encoding any alloantigen in erythrocytes. But blood type $\mathrm{O}$ has glycoprotein at its surface.

\section{METHODS}

This study is a comparative descriptive study, the method used is a survey with data collection techniques using tests and measurements. This study aims to determine the comparison of cardiovascular resistance based on blood type, which results can later be seen what blood type has a better level of cardiovascular endurance.

The samples in this study were 24 students from Sports Science Faculty, Jambi University. The instrument used in this study is the Multistage Fitness Test or MFT.

After obtaining data from the study, then the data were analyzed using comparative descriptive analysis and then continued with the percentage formula. How to calculate percent with a formula, are:

Percentage (\%) $P=-x 100 \%$

Notes:

$\mathrm{f}=$ frequency

$\mathrm{n}=$ Number of Cases

$\mathrm{P}=$ Percentage

\section{RESULT AND DISCUSSION}

From the results of data analysis on the comparison of cardiovascular endurance based on blood type of the students, from 24 samples can be described as follows:
Table 2. Statistic descriptive of endurance comparison based on blood types.

\begin{tabular}{|l|l|}
\hline Statistik & Skor \\
\hline Mean & 44.23 \\
\hline Median & 44.85 \\
\hline Std. Deviation & 6.27 \\
\hline Range & 27.5 \\
\hline Minimum & 31.8 \\
\hline Maximum & 59.3 \\
\hline
\end{tabular}

Based on the table above can be described that the data comparison of cardiovascular endurance based on blood type with an average is 44.23 , mean value is 44.85 , standard deviation value of 6.27 , while the highest value is 59.3, and the lowest value is 31.8 with a distance of 27.5. Furthermore, for the overall data on the acquisition of cardiovascular test results of the students, it can be seen in the table below.

Table 3. Cardiovascular Endurance category of the students

\begin{tabular}{|l|l|l|l|l|}
\hline No & Inverval & Fr & Percentage(\%) & Category \\
\hline 1. & $<35.0$ & 1 & 4.1 & Very bad \\
\hline 2. & $35.0-38.3$ & 2 & 8.3 & Bad \\
\hline 3. & $38.4-45.1$ & 9 & 37.6 & Medium \\
\hline 4. & $45.2-50.9$ & 8 & 33.3 & Good \\
\hline 5. & $51.0-55.9$ & 4 & 16.7 & Very Good \\
\hline 6. & $>55.9$ & 0 & 0.0 & Superior \\
\hline \multicolumn{2}{|l|}{ Total } & $\mathbf{2 4}$ & $\mathbf{1 0 0}$ & \\
\hline
\end{tabular}

From table 3 above, it can be seen that the results of the cardiovascular endurance tests of the students are generally in the medium category. This can be proven by seeing that the highest frequency is in the medium category with a frequency of 9 people or with $37.6 \%$. while athletes with good category are at $33.3 \%$ with a total of 8 people and those in the very good category are 4 people with $16.7 \%$. Furthermore, students with bad categories were 2 people or $8.3 \%$ and very bad categories were 1 person or $4.1 \%$ and students with superior cardiovascular strength were absent.

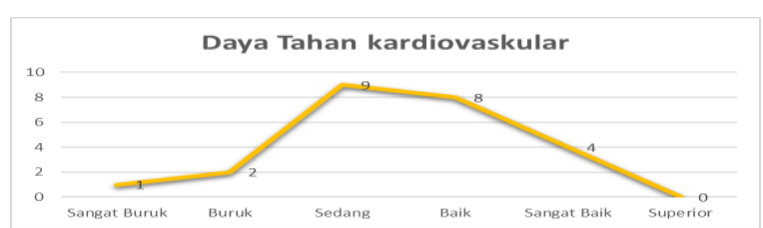

Figure 1. Histogram of cardiovascular endurance of the students

Furthermore, cardiovascular endurance data for each blood group can be seen in the table below. 
Table 4. Distribution of cardiovascular data for each blood types

\begin{tabular}{|l|l|l|l|l|l|}
\hline \multirow{2}{*}{ No } & \multirow{2}{*}{$\begin{array}{l}\text { Blood } \\
\text { Types }\end{array}$} & \multicolumn{2}{|l|}{ Statistics } & \multirow{2}{*}{ Category } \\
\cline { 3 - 6 } & & Mean & Max & Min & \\
\hline 1 & AB & 41.5 & 44.5 & 38.5 & Medium \\
\hline 2 & B & 41.63 & 47.4 & 31.8 & Medium \\
\hline 3 & A & 44.62 & 51.4 & 35.7 & Medium \\
\hline 4 & O & 45.68 & 59.3 & 38.5 & Good \\
\hline
\end{tabular}

Based on the table above, it can be seen that in general, the cardiovascular endurance value of the students of Sports Science Faculty, Jambi University is in the medium category, and also when looked at each blood group, the results showed not much different between $\mathrm{A}, \mathrm{AB}, \mathrm{B}$, and $\mathrm{O}$ blood types. This can be seen in table 4 . where the average value of cardiovascular endurance of students with blood type $A B$ is 41.5 with the medium category. Furthermore, students with blood type B had an average score of 41.63 in the medium category. Next is blood type A with an average value of 44.62 in the medium category. Finally, blood type O shows good results with an average value of 45.68 with a good category. for more detail scan be seen in the histogram below.

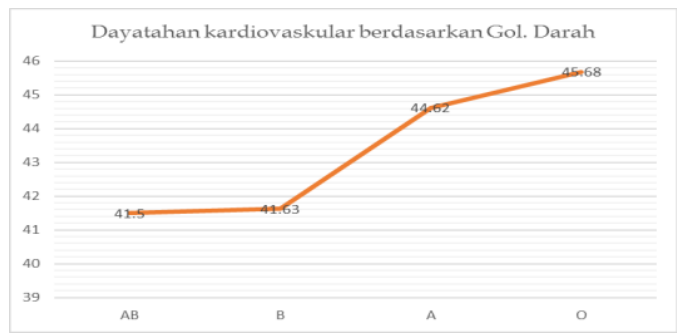

Figure 2. Histogram of cardiovascular endurance for each blood type

Based on the histogram above, we can infer a general conclusion that students with blood type $\mathrm{O}$ have better cardiovascular resistance capacity compared to students with blood types A, AB, and B. From the above data only blood type $O$ has an average rating of bad people in the good category, while other blood groups fall into the medium category.

In accordance with the purpose of this study, only an initial study that wants to see the differences in endurance based on blood types. indeed, from the data analysis, blood type $\mathrm{O}$ showed the result in the good category, but the difference in numbers with other blood types, not so large and significant, where blood types A, $\mathrm{AB}$, and $\mathrm{B}$, showed moderate results.

According to Ida Saraswati [18] in addition to food, also required to exercise and it seems that each type of blood type has a suitable kinds of sport. blood type $\mathrm{O}$, preferably draining sports, such as aerobics or running or exercises related to endurance of the heart muscle, then blood type $\mathrm{A}$ is more recommended for quiet sports such as yoga, blood type B more moderate sports such as mountain climbing, bikin, and blood type $\mathrm{AB}$ is the same as blood type A. Based on this opinion, it can be confirmed that blood type $\mathrm{O}$ has a better cardiovascular endurance level compared to other blood types.

For this initial result it can be concluded that students who have blood type $\mathrm{O}$ have better cardiovascular endurance than blood types $\mathrm{A}, \mathrm{AB}$, and $B$. However this must still be continued with further indepth and specific further research that must pass the test clinical and laboratory testing of cardiovascular resistance.

In this study, all samples were generalized, meaning they were considered the same, this factor that might be more specifically examined in subsequent studies, according to (Dewi Permaesih et al. 2000) factors that affect cardiovascular endurance namely age, body mass index, triglycerides Cholesterol, blood sugar and blood pressure.

Furthermore Efendi [19] suggested that the factors that influence cardiovascular endurance are genetic, age, sex, physical activity and exercise, and smoking habits. For this reason, it is deemed necessary for further research to be able to categorize samples according to the factors mentioned above.

According to experts, in addition to hemoglobin, blood and oxygen, blood type can also affect cardiovascular endurance, for example in Japan and Korea and several other East Asian countries, blood type is not only considered important in medical settings. In everyday relationships, Japanese and Korean people often ask other people's blood types to find out their nature.

People with $\mathrm{O}$ blood type are the happiest in the world, because they are like omnivores, eaters of all things. Therefore, the Japanese prime minister stated that mostgreat Japanese athletes have O blood type, because $O$ blood type matches to all foods and eats everything so he has great power. Meanwhile, many Japanese scientists are in B blood type. Maybe because B blood type people take benefit from eating meat and various kinds of fish, also vegetables that contain lots of protein that make them more intelligent that suitable for scientific work. 


\section{CONCLUSION}

Based on the results and discussion of this research it can be concluded that $\mathrm{O}$ blood type has a higher level of cardiovascular endurance compared to $\mathrm{A}, \mathrm{AB}$, and $\mathrm{B}$ blood types. where $\mathrm{O}$ blood type is in the good category and other blood groups are in the moderate category.

\section{REFERENCES}

[1] Halim, Nur Ichsan. 2011. Tes dan Pengukuran Kesegaran Jasmani. Makassar: Universitas Negeri Makassar
[2] Djoko Pekik Irianto. (2004). Pedoman Praktis Berolahraga untukKebugaran dan Kesehatan. Yogyakarta: Andi Offset.

[3] Irianto, Koes. 2013. Anatomi dan Fisiologi Untuk mahasiswa. Bandung. Alfabeta.

[4] Albertus Fenanlampir dan Muhammad Andri, F., Hurmaly, T. 2013. Diet Sehat Khusus Remaja Berdasarkan Golongan Darah A B Ab O. Bandung.

[5] Saraswati, Ida. 2015. Olahraga dan Makanan Sesuai dengan Golongan Darah. Yogyakarta: Smart pustaka.

[6] Arikunto, Suharsimi. Prosedur Penelitian Suatu Pendekatan Praktik. Jakarta: Rineka Cipta, 2016. 